\title{
ANALISIS KADAR UNSUR NITROGEN (N) DAN POSFORUS (P) DALAM LAMUN (Enhalus acoroides) DI WILAYAH PERAIRAN PESISIR KABONGA BESAR KECAMATAN BANAWA KABUPATEN DONGGALA
}

\author{
The Analysis of Nitrogen (N) and Phosphorus (P) Level in Seagrass (Enhalus \\ acoroides) in Bay Area of Kabonga Besar, Banawa District, \\ Donggala Regency
}

\author{
*Sofyan Ramadhan, Vanny M. A. Tiwow, dan Irwan Said \\ Pendidikan Kimia/FKIP - Universitas Tadulako, Palu - Indonesia 94118 \\ Received 13 December 2015, Revised 15 January 2016, Accepted 14 February 2016
}

\begin{abstract}
The caring of community and local government toward sustainability of seagrass ecosystem has not built properly as well as toward the ecosystem of coral reef and mangrove, as a result, this plant needs attention for its sustainability. One of seagrass's species which is avalaible abundantly in Banawa district Donggala regency, is enhalus acoroides type. This research aims to know the level of Nitrogen dan Phosphorus in enhalus acoroides which grow in the bay of Kabonga besar, Banawa district Donggala regency. Determination of Nitrogen level used Kjeldhal method which consisted of destruction, destilation, titration and Phosphorus used wet ash method which continued to use the UV-Vis Spectrometry. The result showed that the level of Nitrogen in seagrass (enhalus acoroides) type was 1.89 in percentage and phosphorus was 0.413 in percentage.
\end{abstract}

Keywords: Seagrass, kjeldahl method, nitrogen, phosphorus

\section{Pendahuluan}

Wilayah pesisir Indonesia mempunyai keanekaragaman hayati yang cukup tinggi seperti hutan bakau (mangrove), padang lamun, terumbu karang, ikan, mamalia, reptilia dan berbagai jenis moluska. Secara berurutan, kita dapat menemui tanaman bakau, padang lamun, dan terumbu karang di wilayah pesisir pantai. Interaksi ketiga ekosistem ini sangat erat. Struktur komunitas dan sifat fisik ketiga ekosistem ini saling mendukung, sehingga bila salah satu ekosistem terganggu, ekosistem yang lain akan terpengaruh (Tahril, dkk., 2011).

Lamun (Seagrass) adalah tumbuhan berbunga (Angiospermae) yang hidup dan tumbuh di laut dangkal, mempunyai akar, rimpang (rhizome), daun, bunga dan buah serta berkembang biak secara generatif (penyerbukan bunga) dan vegetatif (Kementerian Negeri Lingkungan Hidup, 2004) Pentingnya kehadiran padang lamun di sepanjang pantai

*Correspondence:

Sofyan Ramadhan

Program Studi Pendidikan Kimia, Fakultas Keguruan dan

Ilmu Pendidikan, Universitas Tadulako

email: ramadhansofyan1992.sr@gmail.com

Published by Universitas Tadulako 2016

dan disekitar pulau-pulau kecil terlihat dari banyaknya aktivitas nelayan yang menjadikan padang lamun sebagai daerah pemukiman, pengoperasian alat tangkap ikan, jalur transportasi laut. Kondisi ini menunjukkan bahwa padang lamun dapat mendukung produktivitas perairan pesisir tersebut. Namun perlu disadari bahwa pemanfaatan habitat lamun sebagai aktivitas kegiatan manusia tersebut akan memberikan tekanan ekologis terhadap pertumbuhan dan perkembangan padang lamun dalam melaksanakan fungsi ekologisnya (Kementerian Negeri Lingkungan Hidup, 2004)

Keberadaan lamun masih belum banyak dikenal baik pada kalangan akademisi maupun masyarakat umum, jika dibandingkan dengan terumbu karang maupun bakau (mangrove). Padahal ketiganya merupakan kesatuan yang tak terpisahkan dari wilayah pesisir. Permasalahan yang mendasar dalam pengelolaan ekosistem padang lamun adalah masih kurangnya pemahaman masyarakat dan pemerintah daerah mengenai pentingnya peranan ekosistem padang lamun. Kepedulian masyarakat dan pemerintah daerah terhadap 
pelestarian ekosistem padang lamun belum terbangun secara memadai seperti halnya terhadap ekosistem terumbu karang dan hutan bakau. Hal ini disebabkan karena padang lamun masih dipandang terbatas dari segi fisiknya semata sebagai "rerumputan yang tidak berguna". Banyak kegiatan pembangunan di wilayah pesisir telah mengorbankan ekosistem padang lamun, seperti kegiatan pembangunan kawasan industri, rekreasi atau pelabuhan ternyata terjadi pengurangan terhadap luasan kawasan padang lamun, sehingga pertumbuhan, produksi ataupun biomasanya akan mengalami penyusutan (Sudiarta \& Sudiarta, 2011)

Ekosistem lamun mempunyai peranan penting dalam menunjang kehidupan dan perkembangan jasad hidup di laut dangkal. Lamun mempunyai tingkat produktifitas primer tertinggi bila dibandingkan dengan ekosistem lainnya yang ada di laut dangkal seperti ekosistem terumbu karang. Lamun juga mempunyai hubungan ekologis dengan ikan melalui rantai makanan dari produksi biomasanya (Usman, 2012). Lamun memberikan tempat perlindungan dan tempat menempel berbagai hewan dan tumbuhtumbuhan (alga) (Umar, 2010). Padang lamun juga dapat ditemukan hewan jenis ekhinodermata yang menghuni seluruh padang lamun seperti pada perairan Darunu, Sulawesi Utara telah ditemukan 21 jenis ekhinodermata, keseluruhan jenis terdapat dalam 4 kelas yakni kelas holothuroidea (teripang) diwakili 5 jenis, kelas echinoidea (bulu babi) diwakili 7 jenis, kelas asteroidea (bintang laut) diwakili 5 jenis dan kelas Ophiuroidea (bintang mengular) diwakili 4 jenis (Yusron, 2012).

Daun lamun yang lebat akan memperlambat air yang disebabkan oleh arus dan ombak sehingga perairan di sekitarnya menjadi tenang. Rimpang dan akar lamun dapat menahan dan mengikat sedimen, sehingga dapat menguatkan dan menstabilkan permukaan substrat sesuai pada Gambar 1. Jadi padang lamun yang berfungsi sebagai penangkap sedimen dapat mencegah erosi (Miller \& Sluka, 1999).

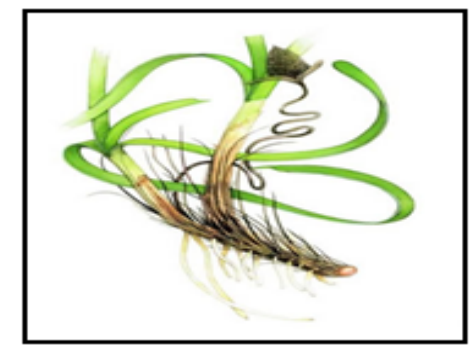

Gambar 1. Lamun Enhalus acoroides
Jumlah dari sinar matahari yang dapat diserap oleh daun kebanyakan bergantung pada pigmennya. Peran dari lingkungan dapat mempengaruhi pigmen daun dan penyerapan sinar matahari (Silva \& Santos, 2003). Variabel lingkungan seperti suhu, salinitas, kecerahan dan secara kimia seperti ketersedian unsur hara dalam lingkungan perairan aka mengakibatkan perubahan komposisi spesies dari komunitas lamun. Perubahan komunitas lamun seperti itu dapat dimanfaatkan untuk memonitor keadaan lingkungan pada saat tersebut dan juga dapat digunakan untuk menduga hubungannya dengan kondisi lingkungan di masa selanjutnya (Tahril, dkk., 2011)

Tanaman mampu menyimpan bagian karbon dari molekul $\mathrm{CO}_{2}$ untuk membangun strukturnya. Analisis siklus karbon pada ekosistem pesisir menunjukkan pentingnya keberadaan vegetasi pesisir seperti alga makro, lamun, dan mangrove, tetapi diabaikan dari penghitungan siklus karbon di lautan. Pengabaian ini dimungkinkan akibat terbatasnya luasan vegetasi pesisir, yang hanya sekitar $<2 \%$ dari permukaan samudera. (Kiswara, 2010)

Secara tradisional lamun telah dimanfaatkan untuk kompos dan pupuk, cerutu dan mainan anak-anak, dianyam menjadi keranjang, tumpukan untuk pematang, mengisi kasur, ada yang dimakan, dibuat jaring ikan. Pada zaman modern ini, lamun telah dimanfaatkan untuk penyaring limbah, stabilizator pantai, bahan untuk pabrik kertas, makanan, obat-obatan dan sumber bahan kimia (Umar, 2010).

Mengingat lamun sangat penting manfaatnya bagi lingkungan dan sumberdaya hayati perairan, maka lamun jenis Enhalus acoroides perlu untuk diperhatikan kelestarian dan juga pertumbuhannya. Pertumbuhan, morfologi, kelimpahan dan produksi primer lamun pada suatu perairan umumnya ditentukan dari ketersediaan posforus, nitrat, dan amonium yang berperan penting dalam menentukan fungsi tanaman lamun (Yamamuro, dkk., 2003). Kandungan nitrat, nitrit dan fospat yang terdapat dalam lamun memiliki variasi konsentrasi pada musim dan lokasi yang berbeda (Thangaradjou \& Kannan, 2007). Oleh karena kandungan posforus dan nitrogen dalam lamun Enhalus aoroides sangat menunjang pertumbuhannya di perairan pesisir Kabonga Besar kecamatan Banawa kabupaten Donggala maka, perlu melakukan penelitian untuk mengetahui berapa besar kandungan posforus dan nitrogen dalam lamun tersebut

Penelitian ini bertujuan untuk menentukan 
kadar nitrogen dan posforus yang terkandung dalam lamun Enhalus, acoroides yang tumbuh di di wilayah perairan pesisir kelurahan Kabonga Besar, kecamatan Banawa, kabupaten Donggala

\section{Metode}

\section{Alat dan Bahan Penelitian}

Alat yang digunakan dalam penelitian ini Alat yang digunakan dalam pengambilan sampel dilapangan antara lain wadah tempat sampel yang kedap cahaya sebanyak 3 buah, gunting. Sedangkan alat yang digunakan dalam laboratorium adalah wadah sampel, spatula, oven, cawan penguap, ayakan 80 mess, mill grinder (Retsch zm 200), gelas ukur, gelas kimia, labu takar, labu takar, pipet tetes, pipet mikro, neraca digital, tabung digestion, turboksoq kjeldhalterm (Gerhardt), destilation vapodest 45s (Gerhardt), Erlenmeyer $500 \mathrm{~mL}$ batang pengaduk, statif, klem, spektrofotometer UVVis $(T 90+p g$ instruments $L t d)$, tabung reaksi, hot plate, magnetic stirrer (Gerhardt).

Bahan yang digunakan pada penelitian ini yaitu sampel lamun, aquades, logam selenium, larutan $\mathrm{H}_{2} \mathrm{SO}_{4}$ pekat (Merck KGaA), indikator metil merah, larutan $\mathrm{H} 3 \mathrm{BO} 3$ (merck), larutan $\mathrm{NaOH} 40 \%$ (Merck), larutan $\mathrm{HNO}_{3}$ 65\% (merck), larutan $\mathrm{HClO}_{4} 60 \%$ (Merck), larutan standar posforus 0-20 ppm, larutan pereaksi $\mathrm{P}$ dan larutan pewarna P.

\section{Prosedur Kerja}

Tahap-tahap prosedur penelitian dikutip dari Sulaeman, dkk., (2005)

\section{Persiapan Sampel}

Sampel yang dikumpulan dari 3 titik kemudian disatukan, lalu dicuci dengan aquades hingga benar-benar bersih kemudian dipotong kecil-kecil, setelah itu sampel dikeringkan dengan oven selama pada suhu $70^{\circ} \mathrm{C}$. Sampel Lamun yang telah kering dihaluskan dengan mill grinder mesin lalu di saring menggunakan ayakan ukuran 80 mess.

\section{Penentuan kadar air}

Timbang seberat $100 \mathrm{~g}$ sampel lamun. Masukkan ke dalam oven yang diset $105^{\circ} \mathrm{C}$ selama 4 jam. kemudian dinginkan dan ditimbang kembali. Kadar air kemudian dihitung menggunakan rumus (Sulaeman, dkk., 2005)

$$
\text { Kadar air }(\%)=\frac{\text { Kehilangan bobot }}{\text { Bobot sampel awal }} \times 100
$$

\section{Penentuan Kadar Nitrogen Tahap destruksi}

Sampel yang telah disiapkan ditimbang sebanyak $0,250 \mathrm{~g}$ lalu dimasukkan dalam tabung digestion Menambahkan $1 \mathrm{~g}$ campuran selen dan 2,5 $\mathrm{mL} \mathrm{H}_{2} \mathrm{SO}_{4}$ pekat. Masukkan 1 g campuran selen dan $2,5 \mathrm{~mL} \mathrm{H}_{2} \mathrm{SO}_{4}$ pekat ke dalam tabung digestion. Selanjutnya. dipanaskan dalam blok digestion hingga suhu $350^{\circ} \mathrm{C}$. Destruksi selesai bila keluar uap putih dan didapat ekstrak jernih (sekitar 4 jam). Tabung diangkat, didinginkan dan kemudian ekstrak diencerkan dengan aquades hingga tepat $50 \mathrm{~mL}$. Kocok sampai homogen, biarkan semalam agar partikel mengendap. Ekstrak jernih digunakan untuk pengukuran $\mathrm{N}$ dengan cara destilasi

\section{Tahap destilasi dan titrasi}

Masukkan $10 \mathrm{~mL}$ larutan ekstrak sampel ke dalam labu didih. Tambahkan sedikit serbuk batu didih dan aquades hingga setengan volume labu. Siapkan penampung $\mathrm{NH}_{3}$ yaitu erlenmeyer yang berisi $10 \mathrm{~mL}$ larutan $\mathrm{H}_{3} \mathrm{BO}_{3}$ $1 \%$ ditambah 2 tetes indikator indikator metil merah (berwarna merah) dan dihubungkan dengan alat destilasi. Tambahkan $\mathrm{NaOH} 40 \%$ sebanyak $10 \mathrm{~mL}$ ke dalam labu didih yang berisi sampel dan secepatnya ditutup. Destilasi hingga volume penampung mencapai 50-75 $\mathrm{mL}$ (berwarna hijau). Destilat dititrasi dengan $\mathrm{HCl} 0,014 \mathrm{~N}$ hingga warna merah muda. Catat volume titar sampel $(\mathrm{Vc})$ dan blanko $(\mathrm{Vb})$. Setelah itu dilakukan perhitungan dengan menggunakan rumus (Sulaeman, dkk., 2005).

Persentase kadar $\mathrm{N}=\frac{(\mathrm{ts}-\mathrm{tb}) \times \mathrm{Normalitas} \mathrm{HCl} \times \mathrm{Ar} \mathrm{N} \times \mathrm{fk} 100 \%}{\text { massa sampel }}$

dimana: $\mathrm{ts}=$ volume titrasi sampel; $\mathrm{tb}=$ volume titrasi blangko; $\mathrm{fk}=$ faktor koreksi kadar air

\section{Penetapan Posforus (metode pengabuan basah)}

Sebanyak 0,500 g sampel lamun ditimbang dan dimasukkan ke dalam tabung digestion. Tambahkan 5 mL larutan $\mathrm{HNO}_{3}$ 60\% dan $0,5 \mathrm{~mL}$ larutan $\mathrm{HClO}_{4} 65 \%$. Selanjutnya dipanaskan dalam digestions blok dengan suhu $100^{\circ} \mathrm{C}$ selama satu jam, kemudian suhu ditingkatkan menjadi $150^{\circ} \mathrm{C}$. Setelah uap kuning habis suhu digestion blok ditingkatkan menjadi $200^{\circ} \mathrm{C}$. Destruksi selesai setelah keluar asap putih dan sisa ekstrak kurang lebih 0,5 $\mathrm{mL}$. Tabung diangkat dan dibiarkan dingin. Ekstrak diencerkan dengan aquades hingga volume tepat $50 \mathrm{~mL}$ dan kocok dengan pengocok tabung hingga homogen. Ekstrak 
ini dapat digunakan untuk pengukuran unsurunsur makro. Pipet secara berturut berturut turut $0 \mathrm{~mL} ; 1 \mathrm{~mL} ; 2 \mathrm{~mL} ; 4 \mathrm{~mL} ; 6 \mathrm{~mL}$ dan $8 \mathrm{~mL}$ larutan standar posforus $20 \mathrm{ppm}$ ke dalam gelas ukur. Tambahkan dengan aquades sehingga volume masing-masing menjadi $10 \mathrm{~mL}$. Deret standar posforus setelah pengenceran ini memiliki konsentrasi secara berturut turur: 0 ppm; 2 ppm; 4 ppm; 8 ppm; 12 ppm dan $16 \mathrm{ppm}$. Pipet masing-masing $1 \mathrm{~mL}$ ekstrak sampel ke dalam tabung kimia dan tambahkan $9 \mathrm{~mL}$ aquades dan dikocok. Dipipet masing masing $2 \mathrm{~mL}$ ekstrak encer sampel dan deret standar posforus $(0-16 \mathrm{ppm})$ ke dalam tabung reaksi. Tambahkan $10 \mathrm{~mL}$ pereaksi pewarna P. Kocok dengan pengocok tabung sampai homogen dan biarkan 30 menit. Kadar P dalam larutan diukur dengan alat spektrofotometer pada panjang gelombang $693 \mathrm{~nm}$ dan dihitung menggunakan persamaan (Sulaeman, dkk., 2005)

$$
\begin{aligned}
& \operatorname{Kadar} \mathrm{P}(\%)=\frac{\text { ppm kurva } x \text { volume ekstrak }(\mathrm{mL}) \times 100 \% \text { x Ar P x fp x fk }}{1000 \times \text { massa sampel }(\mathrm{mg}) \times \mathrm{Mr} . \mathrm{PO}_{4}} \\
& =\frac{\text { ppm kurva } \times 50 \times 100 \times 31 \times 10 \times 1.11}{1000 \times 500 \times 95} \\
& =\frac{\text { ppm kurva } \times 0.1 \times 31 \times 1.11}{95}
\end{aligned}
$$

Dimana: ppm kurva $=$ kadar contoh yang didapat dari kurva hubungan antara kadar deret standar dengan pembacaannya setelah dikoreksi blanko; 100 = faktor konversi ke \%; 1000 = faktor konversi ke ppm (mg/kg); fp = faktor pengenceran (10); $\mathrm{fk}=$ faktor koreksi kadar air

\section{Hasil dan Pembahasan}

Pada penelitian ini sampel lamun Enhalus acoroides yang telah diperoleh harus dicuci bersih dengan air untuk menghilangkan pasir dan zat zat lain yang mungkin melekat pada lamun, setelah itu lamun di keringkan dengan cara di angin anginkan pada suhu ruangan lalu dikeringkan dalam oven dengan suhu $40 \mathrm{oC}$ hingga kering dan dihaluskan dengan menggunakan mill grinder hingga halus lalu diayak dengan ayakan 80 mess untuk memisahkan sampel yang halus. Sampel yang halus kemudian digunakan untuk analisis selanjutnya. Setelah dilakukan penelitian diperoleh data seperti pada Tabel 1.
Tabel 1. Hasil Penelitian lamun

\begin{tabular}{ccccc}
\hline No & Sampel & Kadar air (\%) & Kadar N $(\%)$ & Kadar P(\%) \\
\hline 1 & lamun 1 & 9.7 & 1,921 & $0,417 \%$ \\
2 & lamun 2 & 10,6 & 1,862 & $0,410 \%$ \\
& Rata rata & 10.15 & 1,89 & $0,413 \%$ \\
\hline
\end{tabular}

\section{Kadar Air}

Analisis kadar air dilakukan dengan menimbang $1 \mathrm{~g}$ sampel yang telah halus ke dalam cawan yang telah diketahui bobot kosongnya. Cawan yang berisi sampel kemudian dimasukkan ke dalam oven yang diset $105^{\circ} \mathrm{C}$ selama 4 jam. Pemanasan ini bertujuan untuk menguapkan air yang terikat pada jaringan lamun. Air akan mendidih dan mulai menguap pada suhu $100^{\circ} \mathrm{C}$. Setelah pemanasan cawan penguap yang berisi sampel terlebih dahulu dimasuk, kan dalam desikator lalu ditimbang hingga diperoleh hasil yang konstan. Analisa ini dilakukan sebanyak 2 kali dan diperoleh hasil berturut turut $15,657 \mathrm{~g}$ dan $15,648 \mathrm{~g}$. Setelah itu dilakukan perhitungan sehingga diperoleh hasil pada Tabel 1. Berdasarkan hasil perhitungan diperoleh kadar air rata-rata $10.15 \%$. Kadar air akan digunakan untuk menghitung faktor koreksi, dan diperoleh faktor koreksi kadar air sebesar 1.11. Faktor koreksi kadar air akan digunakan untuk menganalisis kadar Nitrogen dan posforus.

\section{Kadar Nitrogen (N)}

Analisis $\mathrm{N}$ total didasari dengan mengubah $\mathrm{N}$-organik menjadi $\mathrm{N}$-ammonium oleh asam sulfat yang dipanaskan sekitar $380^{\circ} \mathrm{C}$ dan dengan menggunakan katalis. Prinsip, metode kjeldhal yaitu penetapan jumLah secara empiris berdasarkan jumlah $\mathrm{N}$ dalam bahan. Setelah bahan dioksidasi, ammonia (hasil konversi senyawa yang mengandung $\mathrm{N}$ ) bereaksi dengan asam membentuk amonium sulfat. Dalam kondisi basa, ammonia diuapkan kemudian ditangkap dengan larutan asam. Jumlah $\mathrm{N}$ ditentukan dengan titrasi $\mathrm{HCl}$. Metode kjeldhal pada dasarnya dapat dibagi menjadi tiga tahapan yaitu proses destruksi, proses destilasi dan tahap titrasi (Legowo \& Nurwantoro, 2004)

Pada tahap destruksi sampel lamun dipanaskan, dalam asam sulfat pekat sehingga terjadi destruksi menjadi unsur-unsurnya. Elemen karbon, hidrogen teroksidasi menjadi $\mathrm{CO}, \mathrm{CO}_{2}$, dan $\mathrm{H}_{2} \mathrm{O}$. Sedangkan nitrogennya 
akan berubah menjadi $\left(\mathrm{NH}_{4}\right)_{2} \mathrm{SO}_{4}$. asam sulfat yang dipergunakan untuk destruksi diperhitungkan adanya bahan protein lemak dan karbohidrat.

Untuk mempercepat destruksi perlu ditambah katalisator berupa campuran $\mathrm{Na}_{2} \mathrm{SO}_{4}$ $\& \mathrm{HgO}(20: 1)$, atau campuran $\mathrm{K}_{2} \mathrm{SO}_{4} \mathrm{CuSO}_{4}$ dan Selenium. Reaksi pada saat destruksi adalah sebagai berikut :

$$
(\mathrm{CHON})+\mathrm{O}_{\mathrm{n}}+\mathrm{H}_{2} \mathrm{SO}_{4} \longrightarrow \mathrm{CO}_{2}+\mathrm{H}_{2} \mathrm{O}+\left(\mathrm{NH}_{4}\right)_{2} \mathrm{SO}_{4}
$$

Selenium dapat mempercepat proses oksidasi karena zat tersebut selain menaikkan itik didih juga mudah mengadakan perubahan dari valensi tinggi ke valensi rendah atau sebaliknya. Penggunaan selenium lebih reaktif dibandingkan merkuri dan kupri sulfat tetapi selenium mempunyai kelemahan yaitu karena sangat cepatnya oksidasi maka nitrogennya justru mungkit ikut hilang. Hal ini dapat diatasi dengan pemakaian selenium yang sangat sedikit yaitu kurang dari $0,25 \mathrm{~g}$. Proses destruksi sudah selesai apabila larutan menjadi jernih atau tidak berwarna (Legowo \& Nurwantoro, 2004).

Proses selanjutnya ialah destilasi, yang bertujuan untuk memisahkan zat yang diinginkan, yaitu memecah amonium sulfat $\left(\mathrm{NH}_{4}\right)_{2} \mathrm{SO}_{4}$ menjadi amonia $\left(\mathrm{NH}_{3}\right)$ dengan menambahkan $\mathrm{NaOH}$ lalu dipanaskan. Fungsi penambahan $\mathrm{NaOH}$ adalah untuk memberikan suasana basa, karena reaksi tidak dapat berlangsung asam. Ammonia yang dibebaskan selanjutnya akan ditangkap oleh larutan asam standar. Asam standar yang dpat dipakai adalah larutan asam borat $\left(\mathrm{H}_{3} \mathrm{BO}_{3}\right)$ $4 \%$ yang sebelumnya telah dicampur dengan indikator metil merah. Destilasi diakhiri bila semua ammoniak telah teroksidasi sempurna dengan ditandai destilat tidak bereaksi basa. Proses distilasi dihentikan ketika hasil destilat berwarna biru (Legowo \& Nurwantoro, 2004).

Asam borat yang bereaksi dengan ammonia dapat diketahui dengan titrasi dengan menggunakan asam klorida $0,1 \mathrm{~N}$ dengan indikator metil merah, akhir titrasi ditandai dengan perubahan warna larutan dari biru menjadi merah muda. Selisih jumLah titrasi sampel dan blanko merupakan jumlah ekuivalen nitrogen. Blanko berfungsi sebagai faktor koreksi terhadap senyawa $\mathrm{N}$ yang berasal dari pereaksi yang digunakan (Legowo \& Nurwantoro, 2004).

Pada penelitian ini sampel di uji sebanyak 2 kali diperoleh hasil seperti pada Tabel 1. Kadar nitrogen yang dihasilkan yakni 1,921\% dan
$1,862 \%$. Setelah dirata- ratakan menjadi 1,89\%. Nitrogen $(\mathrm{N})$ merupakan salah satu unsur hara utama dalam tanah yang sangat berperan dalam merangsang pertumbuhan dan memberi warna hijau pada daun. Peran nitrogen bagi tanaman adalah untuk merangsang pertumbuhan secara keseluruhan khususnya batang, cabang, dan daun, serta mendorong terbentuknya klorofil sehingga daunnya menjadi hijau, yang berguna bagi proses fotosintesis. Selain itu nitrogen berfungsi mempercepat pertumbuhan tanaman, menjadikan daun tanaman menjadi lebih hijau dan segar serta banyak mengandung butir-butir hijau daun yang penting dalam proses fotosintesis (Marliani, 2011)

Lamun (Seagrass) dapat berkembang biak secara generatif (penyerbukan bunga) dan vegetatif (Kementerian Negeri Lingkungan Hidup, 2004). Perkembangbiakan secara generatif memerlukan bunga jantan dan bunga betina. Biomassa dari dari daun, akar dan rhizoma dari lamun yang berbunga lebih besar daripada lamun yang tidak berbunga. Untuk memproduksi bunga lamun jenis Enhalus acoroides membutuhkan serta membutuhkan nitrogen sebesar $14,8 \pm 1.1 \mathrm{mg} \mathrm{N}(2,2 \pm 0,1 \%)$. Untuk membentuk bunga pada tangkai jantan dibutuhkan nitrogen sebesar 3,8 0 ,3 mg $(2,1 \pm 0,1 \%)$ dan untuk membentuk buah diperlukan nitrogen sebanyak $63,2 \pm 4,9 \mathrm{mg}$ $(1,5 \pm 0,1 \%)$. Lamun jenis Enhalus acoroides yang ada di kabupaten Banawa memiliki kadar nitrogen 1,89\%. Dengan demikian, berdasarkan kadar nitrogennya lamun tersebut dapat berbuah, namun untuk berbunga baik jantan maupun betina diperlukan lebih banyak nitrogen (Rollon, dkk., 1999) sehingga lamun jenis Enhalus acoroides yang ada di kabupaten Banawa berkembangbiak dengan cara vegetatif (rhizoma).

Lamun jenis enhalus acoroides yang ditemukan di lokasi yang berbeda di Filipina berkisar 1,3-2,1\% (Rollon, dkk., 1999). Konsentrasi nitrogen dalam daun berbagai jenis lamun dalam satu lokasi memberikan variasi yang berbeda berkisar 2,1-3,1\%. Lamun jenis Thalassia hemprichii memiliki kadar nitrogen berkisar 2,5-3,0\% sedangkan jenis Syringodium isoetifolium yang ada di jepang memiliki kadar berkisar 0,81-1,04\% (Yamamuro, dkk., 2003). Kandungan nitrogen lamun jenis Enhalus acoroides yang ada di kabupaten Banawa lebih besar daripada jenis Syringodium isoetifolium yang ada di jepang dan lebih kecil daripada lamun jenis Thalassia hemprichii yang ada di Australia dan Jepang. 


\section{Kadar Posforus (P)}

Untuk menganalisis kadar P dalam sampel lamun, digunakan metode destruksi basah yakni, perombakan sampel dengan asam-asam kuat baik tunggal maupun campuran, kemudian dioksidasi dengan menggunakan zat oksidator. Pada metode destruksi basah dekomposisi sampel dilakukan dengan cara menambahkan pereaksi asam tertentu ke dalam suatu bahan yang dianalisis. Asam-asam yang digunakan adalah asam-asam pengoksidasi seperti $\mathrm{H}_{2} \mathrm{SO}_{4}$, $\mathrm{HNO}_{3}, \mathrm{H}_{2} \mathrm{O}_{2}, \mathrm{HClO}_{4}$, atau campurannya. Pemilihan jenis asam untuk mendestruksi suatu bahan akan mempengaruhi hasil analisis (Kristianingrum, 2012). Pada penelitian ini di gunakan sampel lamun sebanyak 0,500 g sampel Lamun ke dalam tabung digestion. kemudian ditambahkan dengan Menambahkan 5 mL larutan $\mathrm{HNO}_{3} 60 \%$ dan $0,5 \mathrm{~mL}$ larutan $\mathrm{HClO}_{4}$ 65\% kemudian didiamkan hingga diperoleh larutan jernih, yang menunjukkan bahwa semua konstituen yang ada telah larut sempurna atau perombakan senyawa-senyawa organik telah berjalan dengan baik. Besoknya dipanaskan dalam dengan suhu $100^{\circ} \mathrm{C}$ selama satu jam, kemudian suhu ditingkatkan menjadi $150^{\circ} \mathrm{C}$. Setelah uap kuning habis suhu digestion blok ditingkatkan menjadi $200^{\circ} \mathrm{C}$. Destruksi selesai setelah keluar asap putih dan sisa ekstrak kurang lebih 0,5 mL. Tabung diangkat dan dibiarkan dingin. Larutan ekstrak yang dihasilkan diencerkan dengan aquades hingga volume tepat $50 \mathrm{~mL}$ dan di aduk menggunakan magnetic stirer tabung hingga homogen (Sulaeman, dkk., 2005).

Larutan standar posforus dibuat dengan mengencerkan larutan standar posforus 1000 ppm menjadi 500 ppm lalu diencerkan lagi $250 \mathrm{ppm}$, lalu $100 \mathrm{ppm}$ hingga $20 \mathrm{ppm}$. Setelah itu dengan menggunakan pipet digital, larutan ekstrak sampe di ambil berturut turut $0 ; 1 ; 2 ; 4 ; 6 ; 8$ dan $10 \mathrm{~mL}$ larutan standar posforus $20 \mathrm{ppm}$ ke dalam tabung reaksi. Tambahkan dengan aquades sehingga volume masing-masing menjadi $10 \mathrm{~mL}$. Deret standar ini memiliki kepekatan: 0; 2; 4; 8; 12 dan 16 . Pipet masing-masing $1 \mathrm{~mL}$ ekstrak sampel ke dalam tabung kimia.Tambahkan $9 \mathrm{~mL}$ aquades dan mengocok. Dipipet masing masing $2 \mathrm{~mL}$ ekstrak encer sampel dan deret standar Posforus (0-16 ppm) ke dalam tabung reaksi. Tambahkan $10 \mathrm{~mL}$ pereaksi pewarna $\mathrm{P}$ dikocok dengan sampai homogen dan biarkan 30 menit.

Pada metode penentuan Posforus dengan menggunakan asam askorbat/molybdate, Senyawa amonium molybdate dan Kalium antimony tartrate akan bereaksi dengan senyawa ortofosfat yang ada dalam jaringan tanaman, dengan suasana asam membentuk senyawa asam phosphomolydic. Konsentrasi dari Posforus dalam larutan tersebut dapat di ukur menggunakan autoanalyzer (Amin \& Flowers, 2004)

Tahap selanjutnya ialah mengukur larutan standar Posforus (0-16 ppm) menggunakan alat spektrofotometer UV-VIS. Hal ini bertujuan untuk memperoleh konsentrasi sampel dengan menggunakan persamaan regresi yang diperoleh dari pengukuran absorbansi larutan standar, yaitu adalah $Y=0,0098 x+0095$ dengan $R 2=$ 0,9784 Tahap berikutnya adalah pengukuran absorban sampel yang dilakukan sebanyak dua kali perlakuan dan nilainya. yakni 0,208 dan 0,206 . dengan menggunakan persamaan regresi tersebut diperoleh nilai $\mathrm{P}$ masing-masing $0,417 \%$ dan 0,410\%, Setelah dirata-ratakan menjadi $0,412 \%$ seperti pada Tabel 1 .

Kadar posforus dalam lamun Enhalus acoroides yang ada di kecamatan Banawa kabupaten Donggala adalah 0,412\% sedangkan lamun jenis yang sama yang tumbuh di Tanjung Bolinao yang ada di Filipina memiliki kandungan posforus berkisar 0,30-0,47 \%. Hal ini menunjukkan bahwa lamun yang ada di kabupaten Banawa memiliki kadar posforus yang sama banyaknya dengan lamun Enhalus acoroides ada di $\mathrm{Tj}$. Bolinao, Filipina (Rollon, dkk., 1999)

Untuk memproduksi bunga betina, selain dibutuhkan nitrogen, juga dibutuhkan posforus sebanyak $2,3 \pm 0,6 \mathrm{mg} \mathrm{P}(0,45 \pm 0,00 \%)$. Untuk memproduksi bunga pada tangkai diperlukan posforus sebanyak $0,8 \pm 0,3 \mathrm{mg} \mathrm{P}(0,40 \pm 0,02 \%)$. Untuk berbuah lamun membutuhkan posforus $14,6 \pm 0,5 \mathrm{mg}$ P $(0,34 \pm 0,02 \%)$. Kadar Posforus pada lamun Enhalus acoroides yang ada di kabupaten Banawa, sebanyak 0,413\%, sehingga dapat disimpulkan bahwa kadar posforusnya telah mencukupi untuk berbuah. Namun untuk berbunga, baik jantan ataupun betina dan berbuah diperlukan Posforus dan Nitrogen yang sesuai. Bila bunga tidak terbentuk maka lamun akan berkembang biak secara vegetatif (Rollon, dkk., 1999). Lamun jenis Enhalus acoroides, membutuhkan waktu yang lama untuk berkembangbiak secara vegetatif (Sambara, 2014)

\section{Kesimpulan}

Kadar nitrogen dalam lamun Enhalus acoroides yang terdapat di perairan pesisir Kabonga Besar, kecamatan Banawa, kabupatens Donggala ialah 1,89\% dan kadar Posforusnya 
(P) sebanyak $0,413 \%$.

\section{Ucapan Terima Kasih}

Ucapan terima kasih penulis berikan kepada laboran Laboratorium Agroteknologi FAPERTA Universitas Tadulako yang banyak membantu penulis dalam menyelesaikan penelitian ini.

\section{Referensi}

Amin, M. \& Flowers, T. H. (2004). Evaluation of kjeldahl digestion method Journal of Research (Science) Bahauddin Zakariya University, Pakistan, 15(2), 159-179.

Kementerian Negeri Lingkungan Hidup, K. (2004). no. 200 tentang Kriteria baku kerusakan dan pedoman pnentuan status padang lamun.

Kiswara, W. (2010). Potensi padang lamun sebagai karbon rosot dan peyerap karbon di pulau pari, Teluk Jakarta. Oseanologi dan Limnologi di Indonesia, 36(3), 361-376.

Kristianingrum, S. (2012). Kajian berbagai proses destruksi sampel dan efeknya. Paper presented at the Seminar Nasional MIPA UNY, Yogjakarta.

Legowo, A. M. \& Nurwantoro. (2004). Analisis pangan. Semarang: UNDIP Press.

Marliani, V. P. (2011). Analisis kandungan hara $N$ dan $P$ serta klorofil tebu transgenik $I P B 1$ yang ditanam di kebun percobaan Pg Djatirojo, Jawa Timur. Institut Pertanian Bogor. Bogor.

Miller, M. W. \& Sluka, R. D. (1999). Patterns of seagrass and sediment nutrient distribution suggest Antrhopogenic enrichment in Laamu Atollm Republic of Maldives. Marine Pollution bulletin, 38(12), 11521156.

Rollon, N. R., Steveninck, E. R. \& Vierssen, W. (1999). Spatio-temporal variation in sexual reproduction of the tropical seagrass enhalus acoroides (L.f) royle in Cape Bolinao, NM Philippines. Aquatic Botany, 76, 339-354.
Sambara, Z. R. (2014). Laju penjalaran rhizoma lamun yang ditransplantasi secara multispesies di pulau Barang Lompo. Universitas Hasanuddin. Makassar.

Silva, J. \& Santos, R. (2003). Daily variation pattern in seagrass photosynthesis along a vertical gradient S. Marine Ecologi Progress Series, 257, 37-44.

Sudiarta, I. K. \& Sudiarta, I. G. (2011). Status kondisi dan identifikasi permasalahan kerusakan padang lamun di Bali. Jurnal Mitra Bahari, 5(2), 104-126.

Sulaeman, Suparto \& Eviati. (2005). Analisis kimia tanah, tanaman, air dan pupuk. Bogor: Balai penilitian tanah dan pengembangan penelitian, Departemen Pertanian.

Tahril, Taba, P., Nafie, N. L. \& Noor, A. (2011). Analisis besi dalam ekosistem lamun dan hubungannya dengan sifat fisikokimia perairaan pantai Kabupaten Donggala. Jurnal Natur Indonesia, 13(2), 105-111.

Thangaradjou, T. \& Kannan, L. (2007). Nutrient characteristics and sediment texture of the seabeds of the Gulf of Mannar. Journal of Environment Bbiology, 28(1), 2933.

Umar, T. (2010). Ekosistem padang lamun. Jurnal Ilmiah Agribisnis dan Perikanan (Agrikan UMMU-ternate), 3(1), 9-29.

Usman. (2012). Teknik penetapan nitrogen total pada contoh tanah secara destilasi titrasi dan kolorimetri menggunakan autoanalyzer. Buletin Teknik Pertanian, 17(1), 41-44.

Yamamuro, M., Kayanne, H. \& Yamho, H. (2003). $15 \mathrm{~N}$ of seagrass leaves for monitoring antrogenic nutrient increase in coral reef ecosystems. Marine Pollution bulletin, 46, 452-458.

Yusron, E. (2012). Ekhinodermata di padang lamun perairan Darunu, Minahasa Utara, Sulawesi Utara. Oseanologi dan Limnologi di Indonesia, 38(2), 181-188. . 